\title{
Gendered Strategies among Northern Migrants in Ghana: The Role of Social Networks
}

\author{
Mariama Zaami
}

\begin{abstract}
The migration trends from Northern to Southern Ghana is not a new phenomenon and it is rooted in historical antecedents. Migration scholars in Ghana have attributed these migration trends from an economic lens, arguing that migration has become a household strategy to diversify incomes. However, little research has focused on social networks serving as migration channels for migrants in the informal sector. In view of this, this paper explores the gendered strategies and social networks that the northern migrants use to gain access to the labour market. This study used a qualitative approach. Primary data was collected using the in-depth interview tool. A sampled population of 58 (37 women and 21 men) migrants from Northern Ghana to the Greater Accra Region (Madina), constituted the respondents. Findings indicate that integration and assimilation of migrants into their new community is a function of ethnicity. Strong and weak social ties facilitate migration differently. Whereas the former facilitates migration, the latter offers an enduring support for new migrants in searching for jobs and accommodation on arrival. The study concludes that knowledge of how social networks organize gender strategies within the migration continuum is important for policy intervention to close the poverty gap between North and South.
\end{abstract}

Keywords: Social Networking, Gendered Strategies, Migration, Ethnicity, Ghana.

Disclaimer: This paper is part of an Mphil thesis which has been submitted online (bora.uib.no)

Department of Geography and Resource Development. College of Humanities, University of Ghana, Legon. Email: mzaami@ug.edu.gh

Ghana Journal of Geography Vol. 12 (2), 2020 pages 1-24

https://dx.doi.org/10.4314/gjg.v12i2.1 


\section{Introduction}

Migration responds to the forces of globalization as well as the interconnectedness of places that facilitate how people move. Demands for labour services is a consequence of the forces of globalization. This means that the movement of people across boundaries has become much more fluid. The network of places has occasioned numerous job openings across space. In this regard, migrants are well positioned to compare labour services outside and within the home (Alcala, 2006). Awumbila (2015) defines internal migration as migration inside as well as international migration across borders. Various reasons could account to these migrations both within and across international borders. These reasons stem from political, social, family unification and economic. For instance, an individual will migrate to join their spouses in the destination area, or another could also migrate because of political instabilities in their countries of origin. The variation in movement could be either 'voluntary' or 'forced' in nature (Jolly \& Reeves, 2005). Forced migration is experienced when migrants flee from their countries of origin because of political persecutions or also due to environmental factors (Teye, 2018).

Migration has shaped the economic and social livelihoods of the global South. The economic and social impacts of migration on the 'left behind' is enormous. Economically, migrants tend to send remittances to their home countries while contributing to the host country's socioeconomic development. Most scholars have attributed the increase in migration to the economic strategy where poor households use it as a livelihood strategy to escape poverty (Awumbila, Owusu \& Teye, 2014; Hagen-Zanker \& Mallett, 2016). Labour migration is the predominant form of migration in the global South pursued by migrants to diversify their livelihoods by sending back remittances. Remittances are the person-to-person flows from migrants to their family and friends. These remittances include money, goods in-kind, and foodstuffs sent through money transfers or hand-carried to migrants' households. Similarly, Awumbila and Ardayfio-Schandorf (2008), have argued that migration in Ghana has become a household survival strategy for individuals and families from Northern Ghana. However, movement of people from the Northern Regions (made up of Northern, Upper East, and Upper 
West Regions ${ }^{1}$ ) of the country to the South of the country (particularly the Greater Accra Region), which is economically productive is rooted in colonial and post-colonial times. According to them, other factors accounting for the North-South movement include environmental problems, ethnic conflicts, and endemic poverty (Awumbila \& ArdayfioSchandorf, 2008; Awumbila, 2015; Mensah- Bonsu, 2003; van der Geest, 2011). Consequently, most natives of Northern Ghana use migration to the South as an economic improving strategy. In recent times, the trend has changed. More women, on their own initiative migrate to the cosmopolitan centres in the South of Ghana, where they work as head porters (kaya yei) (Awumbila \& Ardayfio-Schandorf, 2008).

\section{Literature Review}

Studies have shown that in Africa, the migration of women is not a new phenomenon (Adepoju, 2002; Awumbila et al., 2014; van der Geest, 2011; de Haas, 2007). Posel (2004) showed that female migration had played a key role in diversifying incomes, attributed to labour migration. There has been a predominantly North-South migration within Ghana's context, rooted in economic, political, and environmental factors. The pre-colonial times witnessed some forms of movement of people in exchange for goods and services and trading, but with the arrival of the Europeans in Ghana saw the creation of borders (Songsore, 2009). The colonial government's focus was on producing export crops on plantations and minerals (Songsore, 2009; Yaro, 2006; Awumbila \& Ardayfio-Schandorf, 2008). Given that most of these resources were found in the southern part of the country, northern Ghana became a labour reserve to feed the plantations and mineral sectors (Yaro, 2013). It led to the underdevelopment of the northern sector because most of the infrastructure development was in the South. With the development of infrastructure concentrated in the southern parts, there became an unequal development level, thereby leading to the southern sectors becoming more urbanized than the northern part of Ghana (Songsore, 2009; Yaro, 2006). In addition, post-colonial policies such as the structural adjustment program (SAP) failed to address this developmental gap. The World Bank and International Monetary Fund (IMF) oversaw the implementation of the SAP in 1983. The implementation of the SAP affected Ghana's economy, specifically on access to health,

\footnotetext{
1. The data for the study was generated before the creation of the new regions.
} 
education, and essential services. SAP affected Ghana differently. It however, did not result in poverty reduction. Instead, the gap between the rich and poor increased. Similarly, the rural and urban divide also widened (Yaro, Teye \& Bawakyillenuo, 2015; Bob-Milliar, 2011).

Aside, the governmental policies, some authors have argued that the environmental conditions that prevail in the northern sector- the prolonged dry season and shorter rainy season makes people tend to migrate to seek job opportunities in fertile lands and urban centres in the South. The literature on migration, climate change, and livelihoods demonstrates interlinkages, and people tend to migrate because of climatic shocks (Ellis, 2003; Deshingkar, 2012). About 70\% of Africans's livelihood are dependent on rain-fed agriculture (van der Geest, 2011; Teye, 2018). It has been observed that in many parts of Africa, drought has played a crucial role in the movement of people to other parts for either a short term or long term to diversify their livelihoods (Mensah-Bonsu 2003; van der Geest, 2011; Teye, 2018). For instance, in Burkina Faso, climate change influences short-term migration, a diversification strategy compared to long-term migration, which migrants tend not to have the available resources (Henry, Schoumaker \& Beauchemin, 2004). In a study by Rademacher-Schulz, Schraven, and Mahama (2014) and van der Geest (2011), the authors identified a livelihood strategy used by the people in the upper west and upper east regions, was the dry-season migration to farming and mining communities. This observation was also confirmed by Mensah-Bonsu (2003) who explained that people undertake seasonal labour migration to coastal and urban centres to diversify their livelihoods because of the variability in the rainfall patterns. For instance, Nadowli district has witnessed a fluctuating raining pattern for the past 20 to 30 years, which has affected the region's livelihoods and food security (Rademacher-Schulz et al., 2014).

Most scholars have identified that young abled migrants are forced to migrate to farming communities during the rainy season to address issues of household food insecurity. They further identified some short-term livelihood strategies used by the migrants, some of include the sale of some of their assets, controlling the food consumption and using migration as a livelihood strategy to diversify their incomes. In Ghana, migrant farmers from the northern regions migrate to the southern regions (Brong-Ahafo and Ashanti) where there are fertile lands to engage in farming activities (Van der Geest, 2011; Mensah-Bonsu, 2003). Migrants can access farmlands through various lease arrangements or work as hired labourers on plantations (Van der Geest, 2011). Findings from Van der Geest (2011) study about the Dagara migration 
indicated that people moved because of many factors, including scarcity of land, infertility of the land, and unreliable rainfall. Researchers conclude that these migration patterns could have an adverse effect on the left behind in terms of household food security. In the post-colonial era, migration is still ongoing just that it has been more feminized than previously, where the males dominated the migration process.

Awumbila and Ardayfio-Schandorf's (2008) study of female porters' migration and livelihood strategies from the North to the South demonstrates that migration is being used as a livelihood strategy. Concerning the kaya yei's ${ }^{2}$ (female porters), as young as age eight (8) migrate independently from the rural areas to the urban centres searching for job opportunities. While this decision to migrate is seen as an individual decision, Chant (1998) argued that this decision to migrate is not devoid of the household conditions that inform the process of migration. To understand migration as part of a livelihood strategy of both the individual and the family, issues of both reproduction and production must be considered. These migrant labour opportunities have diverse economic and social implications in both origin and destination (de Haan, 1999).

As mentioned earlier, in Ghana, rural communities are changing rapidly. They do not rely on only one livelihood source for sustenance; instead, they engage in different livelihoods. Therefore, in recent times, families are diversifying their household incomes; thus, women and children have joined in earning income for the household; and not only the male-headed household needs to provide for the family. As this livelihood diversification is ongoing, one of the primary sources of these livelihoods is migration. Regarding Nigeria, poverty has driven most women to join in the migration process because of the challenges in owning land and access to agricultural credits; migration has become a strategy to diversify their household income to support their left-behind families (Adepoju, 2002). The patriarchal system exists in the three northern regions. In this system, the males head families with one or several wives

\footnotetext{
${ }^{2}$ Kayayei- "A name was given to female porters who carry the load on their heads for a negotiated fee" (Awumbila and Ardayfio-Schandorf, 2008, p. 171)
} 
and children. The typical gender roles comprise the husband acting as the head of the family, and controls resources (such as land).

Despite the dwindling rate of economic opportunities for migrants from the north of Ghana, majority of men and women migrants take up the role of providing for the basic sustenance of the family in the face of high costs of living (Awumbila, 2015; Wrigley-Asante, 2008). Although Accra is fast developing with the expectation of a potential in an increase in job opportunities for the migrants, more migrants migrate to the capital town. Because of this, new migrants cannot get access to informal jobs, such as construction works. There is a direct relationship between women's poverty and a number of factors. Some of such factors include absence of economic opportunities and independence, lack of economic resources (including credit, land ownership, and inheritance), lack of access to education and support services, and minimal participation in the decision-making process (Wrigley-Asante 2008).

Various studies of female migration as head porters (kaya yei) exist (Awumbila 2005; Awumbila \& Ardayfio-Schandorf, 2008). The focus of most of these studies has been on female head porters (kaya yei) and the survival strategies they adopt when they migrate to the South. However, few studies have focused on the social networks which these migrants make use of before and after migration. This paper contributes to the scholarly discourse on current trend of migration, with specific interest in the reasons for North-South migration, the kinds of networks involved in the process of migration, and the strategies that Northern women and men use to achieve their aims to migrate to the South. The paper is divided into the following sections: the first section reviews some empirical study on the use of social networks and the conceptual framework- the strength of strong and weak ties as propounded by Granovetter (1995); second section focuses on the data sources and methods. This is followed by the third section, which presents results and findings; the fourth section discusses the results. The last section is the conclusion and policy implications.

\section{Social Network Theory: The Concepts of Strong Ties and Weak Ties}

Many researchers have used social network perspectives to study migration (Awumbila et al., 2017; Yeboah, 2020; Vertovec, 2009). Mitchell (1969, p. 2) defines social networks as "a specific set of linkages among a defined set of persons". The characteristics of these linkages 
are used to interpret the social behaviour of the persons involved. Scholars argue that migrants often use social networks, which serve as channels for migration (Vertovec, 2009; Awumbila et al., 2017). Social networks are significant for migrants in finding a job, accommodation, economic transaction, and, most importantly, psychological support and access to information. A social network may include neighbours or others drawn from the category of kin and ethnic group.

Social networks are essential in understanding the type of ties migrants from the North to urban cities in the Southern parts of Ghana use in migrating. For instance, Afriyie, Abass, and Boateng (2015) showed that social ties connect migrants in origin, and destination areas and had a high tendency of inducing migration. The study used the network theory to attribute migration to personal, cultural, and other social ties. The authors employed the concept of chain migration to explain how social ties can aid in migration. It was observed in this study that migrants reduce the risk and cost involved in the migration process by using social networks. Furthermore, social networks are essential in the decision to migrate. In destination choice, potential migrants often base their decision on the information given to them by their network of friends, family, and other relatives. Likewise, Nikoi, Arthur, and Nambe (2019) using Granovetter's concept of strong ties explained how migrants' networks facilitate and perpetuate migration in time and space by reducing the level of risk.

Similarly, Awumbila, Teye, and Yaro (2017) examined the importance of social capital in migration processes and migrants' livelihood strategies in the informal sector. The authors' focus was on Northern and Volta's migrants working in construction and domestic work. Their study findings demonstrate that these migrants engage in different livelihood strategies in their destination areas, depending on the type of network. It was observed that before migrants move to their destination countries, they usually have some contacts in the destination urban centres before they migrate. Some of these contacts offer financial support and secure jobs for the new migrants. The authors also discovered that both migrants from Volta and northern regions used bonding social capital to integrate into their new destination (Awumbila et al., 2017). However, the authors identified spatial variations because migrants from the Volta region tend to use family networks to migrate. In contrast, northern migrants use friends for information and financial support. The next discussion focuses on the conceptual framework underpinning this study. 
The conceptual framework used for the research is grounded in Granovetter's social network theory of "strong ties" and "weak ties" (Granovetter 1983; 1995). The concept of strong and weak ties was used to classify and analyze the strength of social networks. Granovetter (1995) explained that interpersonal ties could be identified as either strong or weak ties. He identified two types of ties, namely 1) strong ties and 2) weak ties. Strong ties are usually kin-based, from close family members, ethnicity, and class. Weak ties comprise a collection of friends or acquaintances $^{3}$. Granovetter (1995) explained that there are four dimensions to measure the strength of a tie. These are 1) the amount of time spent in interaction, 2) emotional intensity, 3) intimacy, and 4) reciprocal services. These dimensions are not exclusive but are interrelated and interconnected with role relations.

Granovetter (1995) argued that individuals with mostly weak ties are more likely to acquire jobs faster than those with strong ties. He pointed out that members in a kin-based network will access information among the closely-knit networks. However, they are limited in the source of information regarding information outside the immediate kin group. In these situations, the weak ties play a significant role in acquiring relevant information across space and time. The network is widespread for weak ties because a friend could be a friend to someone and a friend to a different person. Therefore, when information is transferred, it moves faster through the weak ties than through strong ties, which are more closely linked (Granovetter 1983).

The paper examines the forms of strong and weak ties that exist among Northern migrants. What kind of ties do they use before and after migration? The nature of ties used by migrants in getting access to information, jobs, and accommodation. The kind of ties used will help determine whether Northern migrants in the study communities predominantly rely on strong ties or weak ties.

\footnotetext{
${ }^{3}$ If the person providing the help is a relative, the tie is considered a strong tie. If the person is an acquaintance, the tie is considered a weak tie
} 


\section{Data Sources and Methods}

\section{The Study Area (Madina)}

Madina is a sub-urban settlement located in the Accra plains - 10 miles northeast of Accra on the Dodowa road. It lies 2 miles north of the University of Ghana, Legon. Madina is a heterogeneous society comprising of people from different social, religious, and ethnic backgrounds. Madina's ethnic composition includes migrants from the Northern Regions (Northern Region, Upper West Region, and Upper East Region), Ga- Dangmes, Ewes, Akans, and non-Ghanaians like Ivorians, Togolese and Nigerians. Religious groups include Christianity, Islam, and African traditional religion. Madina is a community with high concentrations of migrants from the Northern part of Ghana. It has a significant market that serves the other surrounding communities with two market days-Wednesdays and Saturdays of the week.

\section{Field sampling}

This paper is based on semi-structured interview data collected as part of a mixed-method approach to understanding the gendered strategies and social networks used in migration among Northern migrants in Madina. Interviews are opened questions used in exploring individuals, households, or groups experiences of a phenomenon (Creswell, 2009, Moustakas, 1994). Semi-structured interviews are flexible and make it amenable for purposes of generating data for a specific study. Interviews can be structured or unstructured. With an interview guide, questions are either asked face to face, through the telephone, or administered by email. Unstructured interviews are more conversational than questionnaires, which are pre-coded and demands a set of answers. Unstructured interviews allow interviewees to express their experiences and explain a particular phenomenon (Creswell, 2009).

\section{Sample population}

Participants were sampled from the three Northern Regions (Northern, Upper East, and Upper West) (see Table 1). Purposive sampling was used to recruit participants for the study. The inclusion and exclusion criteria were migrants from the three northern regions and working in 
Ghana Journal of Geography Vol. 12 (2), 2020 pages 1-24

the informal economy in Madina, specifically the market and its environs. In contrast, the exclusion criteria were migrants who were not from the selected regions. I relied on the snowball technique in recruiting my participants for the study. First, I was introduced to one migrant from a specific ethnic group. They intend introduced me to other migrants in the Madina market. 
Table 1:Socio-demographic characteristics of participants

\begin{tabular}{|c|c|c|c|c|}
\hline Ethnicity & Gender & Number & Age (yrs) & Type of work \\
\hline \multirow{3}{*}{$\begin{array}{l}\text { Builsa (Doninga } \\
\& \text { Bachonsa) }\end{array}$} & Female & 3 & $25-35$ & Sale of groundnuts \\
\hline & & & & (boiled \& roasted) \\
\hline & Male & 5 & $15-30$ & Truck pushing \\
\hline \multirow[t]{2}{*}{ Frafra } & Female & 2 & $35-45$ & Pito Brewing \\
\hline & Male & 2 & $20-40$ & Truck pushing \\
\hline \multirow[t]{2}{*}{ Dagomba } & Female & 10 & $12-35$ & Kaya yoo, frying of groundnuts \\
\hline & Male & 4 & $15-30$ & $\begin{array}{l}\text { Butchers, sale of goats and } \\
\text { sheep }\end{array}$ \\
\hline \multirow[t]{2}{*}{ Sissala } & Female & 6 & $12-35$ & Kaya yoo, sale of charcoal \\
\hline & Male & 3 & $15-35$ & Truck pushing \\
\hline \multirow[t]{2}{*}{ Mamprusis } & Female & 10 & $12-35$ & $\begin{array}{l}\text { Kaya yoo, frying of } \\
\text { groundnuts, chop bars }\end{array}$ \\
\hline & Male & 3 & $20-30$ & Yam sellers, sale of goat, sheep \\
\hline Dagaaba/Wala & Female & 6 & $30-45$ & $\begin{array}{l}\text { Kaya yoo, brewing of pito, } \\
\text { preparing banku }\end{array}$ \\
\hline Tampluensi/ & Female & 2 & $12-35$ & Kaya yoo \\
\hline Talensi & Male & 2 & $25-35$ & Truck pushing. \\
\hline
\end{tabular}

Source: Field work data, 2009.

The data was analyzed thematically. First, the field data was transcribed verbatim from the different linguistic dialects to the English language for the analysis. Second, I grouped key statements by participants into themes for meaning making. I found statements about the different social ties that migrants use before and after migrating. I treated each statement as having equal worth. Categories were developed from the transcribed data. Themes emerged from the categories which were analyzed thematically. Direct statements from respondents were used for the analysis.

To ensure credibility, I used member checking by having some of my respondents check the transcribed data to ensure that I captured the meanings they gave to their narratives. I also debriefed after all interviews to ensure that participants were privy to the issues we had discussed. 


\section{Results and Findings}

The interviews revealed themes such as gender differences in the flow of remittances, social networks used before and after migration, and the role of ethnic group membership and associations in the integration process.

The findings show that most Northern migrants use migration as a livelihood strategy to diversify income sources to the household. Almost all the participants mentioned the climatic and environmental factors inducing their migration. They indicated that they migrate to the southern part of Ghana during the prolonged dry season and return to their various regions during the rainy season to engage in farming. Given the reasons for migrating, most of the income earned in the destination area is sent home to take care of the household's basic needs. Findings indicate that the income migrants get from working in the informal sector differ for gender, age, and marital status. Most married women and men send remittances in the form of money and in-kind for the household. For example, remittances are used for the household's immediate consumption, namely food expenses, school fees, and health care. However, the flow of remittances is different. The women explain that the money they receive from their work is sent home immediately whiles the men explain that monetary remittances are sent when a critical problem is identified. For the unmarried men and women, the women used their income to purchase cooking utensils in preparation for marriage. They buy a sewing machine to engage in sewing activities when they return home. The young men also save their income to meet their basic needs and save towards paying for their education. This finding concurs with Awumbila and Ardayfio-Schandorf's (2008) study on young female migrants saving towards the acquisition of items towards marriage.

\section{Social Ties used before Migration: From Family Ties to Ethnic Ties}

Many scholars explain that kinship ties have been a significant channel for migration Awumbila et al., 2017; Yeboah, 2017). However, from the findings, although migrants use the kinship ties before migrating, most of them turn to ethnic group members for support in settling in Madina. One of the participants elaborated on her experience:

My husband is deceased, and I have two children as my responsibility. After my husband's death, I migrated to Madina to work and get money to take care of my two 
children. Before I left Wa for Accra, I contacted my uncle's daughter (cousin). My cousin lived and worked at Tema fishing harbor. Therefore, I lived with her at Tema before I came to Madina. I did not contact anyone before I moved to Madina. When I got to Madina, I identified the kaya yei girls and joined them in the business. At night, I identified the Wala group and joined them to spend the night (Salamatu, F, 30, Wala).

In the quote above, the participant migrated to Accra because the cousin lived in Accra. As such, the cousin provided her with accommodation. Salamatu decided to move to Madina, and during relocation, she mentioned she had no contacts at Madina. However, when she arrived in Madina, she identified herself with her ethnic group members (the Wala ethnic group). They provided her with social support, such as accommodation, and introduced her to the kaya yei business.

In Salamatu's narrative, we realize that there are different networks used before and after migration. Another participant had this to say:

When I lost my husband, I contacted my elder sister, who lived in Madina and worked as a Ridge hospital nurse. I informed my sister that I wanted to migrate to Madina to work to take care of my child because my husband died... and my elder sister agreed. I migrated from Nandom to Madina in search of work. On arrival, I told my elder sister I wanted to start brewing the pito. Therefore, my elder sister took me to Madina urban council and acquired a place to set up the pito brewing place. My sister gave me money to acquire the place and start-up capital to start the business. I did not pay back the money to my sister. In our family, siblings must help each other". (Lariba, F, 44, Dagao)

Lariba's narrative identify the family network as vital in her migration process. The participant indicated that she contacted her sister before embarking on the migration. She assured her of assisting her in gaining employment to support her family after she lost her husband. She explained that the sister provided the initial capital to start the pito (local drink) brewing business. The pito brewing business would not have been possible if the sister were not in Madnia and provided her with all the support she needed to integrate into Madina. Awumbila et al., (2017) study of Northern and Volta migrants explain how migrants receive social capital to cope with the shortcomings associated with living in urban centres as migrants. The authors identify migrants' social capital as the information received about the destination, financial support, and initial accommodation to new migrants. The authors also explain spatial variations because migrants from the Volta region rely on family networks to migrate. In contrast, northern migrants rely on friendship networks for information and financial support. 
Regarding the type of jobs performed by the migrants, it is observed that migrants from the Volta region focus on construction activities, thereby recruiting family members. Additionally, the type of work done by these migrants is gendered. Females are more likely to engage in domestic work they acquire through friends and other family relatives. Likewise, Afriyie et al. (2015) and Yeboah (2020) identify how young migrants use social networks to access jobs and accommodation when they migrate to the South.

Some participants also use kin-ship ties to continue with their formal education as in Stephen's case. In Stephen's situation, things took a different turn when he arrived in Accra. In Stephen's own words:

I am a final year student at Accra Polytechnic. I left Sadema in 2006 to live with my uncle (mother's brother) at Madina to continue my education after I completed Senior High School. My uncle was a truck pusher, and he died the same year I migrated to Madina. I had to look for a means to survive and to achieve the aim of coming to Accra. I resolved to join in truck pushing for survival. Madina's survival is highly dependent on the ethnic group members I have in Madina (Stephen, M, 25, Builsa).

Stephen's migration trajectory is that of a strong tie. He did not migrate to work in the informal economy but to continue with his education. It was an unfortunate situation for him when his benefactor passed on. He relied on ethnic ties for economic and social support regarding access to the truck pushing because they worked in groups to support each other. According to Stephen, through the savings, he took care of his basic needs and to pay his school fees to continue his formal education. There are no gender differences in the type of support northern migrants receive in Madina from ethnic group members. Most of the participants reiterated that the ethnic groups in Madina were in associations. Associations help the migrants to identify group members' needs and offer the needed support in times of adversities.

\section{Social Ties Used After Migration}

Migrants' integration in destination areas is tied to the social networks used after migrating. In this study, participants' initial contacts before migration are usually close ties but move quickly out of it when they arrive in Madina. The study reveals that after migration, three types of social ties are used, namely, ethnic group associations, roommates, and occupational association. 


\section{Ethnic Group Membership and Ethnic Associations}

The interviews reveal that ethnicity plays a significant role in migrants' success in Madina. When an individual identifies with an ethnic group, there is a sense of belongingness. As such, they provide each other with the needed support to thrive in Madina.

Migrants are organized in the study area according to ethnic groups (see Table 1). Madina's integration process is in two phases: first, a migrant need to identify with an ethnic group on arrival in Madina. When a migrant identifies an ethnic group, they can access accommodation with the members. The second phase is the job opportunities available in the study area. Depending on the ethnic group the migrant identifies with, he/she is assigned to a particular type of job. For instance, most female migrants from the Dagomba and Mamprusi tribes engage in the kaya yei business, whiles the Frafras and the Dagaaba engage in the pito brewing business. The male migrants are mostly engaged in truck pushing irrespective of the ethnic group. It is easier for female migrants to gain access to a job in the market because it is cheaper to purchase a head pan to start work than a truck/trolley. Because it is expensive to acquire a truck/trolley, male migrants need to work in four and five groups to meet their basic needs. Access to accommodation is also organized according to ethnic groups, and they have invisible boundaries where they live. These boundaries are respected for the peaceful co-existence of members. Participants expressed the importance of ethnic groups when migrants arrived without prior contacts in Madina.

One of the female respondents explained the migration process:

I did not contact anyone in Madina before migrating. However, I hope that when I get to Accra - Madina, I will be able to locate my ethnic group members who also engage in kaya yoo to help me get a place to lay my head and start work (Afishetu, F, 20, Builsa).

As the above quote suggests, Afishetu did not use any form of contact before migrating to Madina. She indicated that she would meet some ethnic group members in Madina who would assist her with the needed support. In Granovetter's concept of strong and weak ties, we realize that the above weak tie serves as a migration channel. With that, the migrant could have access to accommodation and eventually some form of work in Madina's informal economy. Ethnic group members, as respondents indicated, make them feel a sense of belonging and a form of 
acceptance that they identify with the same place of migration. We could relate this to the migrant adaptation process, where migration scholars have explained that migrants establish new social relationships in destination areas. These social relationships enable them easy accessibility to jobs and accommodation (Hashim \& Thorsen, 2011; Yeboah, 2020). The process of adaptation of migrants is illustrated in the quote below:

I am married, and I have a one-year-old child. My husband is a farmer in Sadema Bachonsa. I did not contact anyone before migrating but was introduced to Salamatu, an ethnic group member. She gave me accommodation, and I joined her to work in the market the next day as a kaya yoo (Afishetu, F. 20, Builsa).

The above quote indicates that whiles strong ties play a role in the migration process; ethnic group membership provides social and economic support for easy adaptation to their new home.

Findings also indicate that ethnic associations are well organized in addressing migrants' welfare needs and improving the living conditions of the various ethnic groups. The ethnic associations participate in quite a few social activities, namely weddings, naming ceremonies, and funerals. In addition to these social activities, they also organize regular meetings, and these associational meetings are organized based on gender. For instance, the Sissala ethnic group have male and female groups. The members of the group make a monthly contribution of $\$ 1$ per head for the male group. The female group pay $\$ 7$ because of the microfinance they are organizing to help each other set up small businesses or use the money generated to support each other in times of need. With the female association group, the collection of the monthly dues is done in a rotational system. Each month, the money gathered is given to one group member, which serves as an income buffer for that member. This form of organization the migrants termed it as $s u s u^{4}$.

In addition to the bigger membership group, there are smaller groups, which are organized according to roommates. The roommate group constitute 10 to 20 people. This group offers immediate assistance to members and only elevates issues to the bigger ethnic association if they cannot resolve it at the smaller group level. For example, participants explained that one

\footnotetext{
4 A form of microfinance where each person contributes $\$ 7$ per month.
} 
of the roommates had a two-year-old son who was taken ill. The members in the room had to contribute money to take the son to the hospital. They indicated that these monetary contributions were voluntary, and members contributed to supporting the person, which is reciprocated to other group members. In addition, a roommate's daughter passed on. This time around, it was escalated o the bigger ethnic group where they mourned with the person, and the men took care of the burial rites. Participants explained that tradition forbids the child's mother to follow the men to the burial grounds, so it was solely taken care of by the men. Below is a quote elaborating the role of room membership:

The roommates contribute towards each other's welfare, especially when one of your colleagues is in trouble; failure to contribute towards your colleague's welfare endangers your status in the room, and when you get into trouble, no one will help you (Maimuna, F, 26, Mamprusi)

Roommates are a form of weak social ties that strengthen young migrants' agency by providing social and emotional support for an easy transition into the new environment. The results also reveal that although a group of roommates can be in the same occupation, others also engage in different occupations. However, they retire back to the same room after the day's work. For instance, the women in the roommate group of 20, five (5) will be engaged in the sale of groundnuts, whiles the remaining 15 will be engaged in kaya yei. Almost all the males were truck pushers but belonged to different trucks pushing groups when they got to work in the Madina market.

It is also interesting that the migrants who find themselves in the occupational membership offer support to each other. Certain boundaries are observed, such as not taking someone's regular client from the other. Respondents narrate instances when a person tries to steal another person's client. The group come together to discipline the culprit who faulted the rules of working in the market. Aside from the problems emanating from occupational group members, there are also certain vulnerabilities encountered by the migrants. In the focus group discussions, participants recalled instances where one was accused of carrying stolen goods and was taken to the police station. They had to elevate it to the bigger ethnic group membership quickly. They all matched to the police station, where they all offered financial support to bail the person out. Other vulnerabilities identified by the migrants are the underpayment of customers/clients after carrying the load, refusing to pay, and walking out on 
them, harassment in their line of work by clients/customers and market women, and police brutality. In all challenges they encounter in the market, participants reiterated that ethnic group members play a major role in the safety and smooth transitioning of new migrants in Madina. The findings concur with Awumbila and Ardayfio-Schandorf (2008) and Afriyie et al. (2015) findings of young female migrants and the vulnerabilities they are exposed to in the destination regions. Awumbila et al. (2019) explain that female migrant who engage in domestic work face some forms of abuse, non-payment of their wages, sexual exploitation, and long working hours. In this study, some Northern migrants before migration contact their kinship relations. However, on arrival, ethnic group members assist them. They support them in accessing the available jobs and accommodation. A few migrants contact ethnic group members before migrating. However, most had access to jobs and accommodation through ethnic group members. One of the respondents explained friendship network in the migration process:

I was born at Techiman but migrated from Wungu in the Northern Region of Ghana. I have no education, and I belong to the Mamprusi ethnic group. Before coming to Madina, I contacted a friend because I knew him from the village. My friend sold cocacola on a 'trawler' (wheel bicycle), so I joined him to sell the coca-cola. I did this kind of job for nine months, and I decided to use the money I earned from the sale of the coca-cola to buy a truck to sell yam on it (Alhassan, M, 28, Mamprusi)

From the above quote, we realize that Alhassan uses weak ties before migration, which enabled him to get access to a job immediately he arrived at Madina.

Another participant had this to say about friendship networks:

I came to Madina purposely to work and get money to maintain and expand my business. I returned about seven months ago, but this is my 7 th year since my migrating to Madina. Within the seven years of migrating, I have been able to sell minerals, beer, and bread in the village. When I came to Madina, I stayed for about 6 to 7 months. I returned to invest the money I was operating in Janga. Likewise, when business was bad, I returned to Madina to engage in kaya yoo and the washing of clothes in private houses. I contacted my friends who were in Madina and worked as kaya yoo before migrating. The first time I came to Madina, I joined my friends who had returned to the village from Madina. When I arrived with my friends, they accommodated me, and I became a member of the kaya yoo group from Janga. Where we lived comprised of Mamprusi girls from Janga, the other ethnic groups also had their accommodation. Aside from friendship ties, I was also part of the Mamprusi ethnic association. We contributed money to help one another when there was a problem. There is a feeling of belongingness when one is with the ethnic group members and forms a kind of social security (Azara, F, 22, Mamprusi) 
From the above quote, Azara uses migration as a livelihood strategy to engage in the kaya yoo business and migrates back to Janga to use the income accumulated to expand her business. We also see weak ties in the migration process. Azara relies on friendship ties to aid in the migration and settling process.

We can conclude that there is a blurred line between the types of ties migrants tend to use to migrate to Madina. In some situations, the migrant navigates between weak and strong ties. These ties offer the migrant an opportunity to transition into Madina. The study also reveals that migrants' friends are likely to be from the same ethnic group, which helps in opening job opportunities in the Madina market.

\section{Discussion of Results}

Social networks are important and serve as a medium where information on job opportunities, access to accommodation, emotional, and psychological support are made available (Afriyie et al., 2015; Awumbila et al., 2017; Yeboah, 2018; Vertovec, 2009). Social networks served as channels for migration for the northern migrants in Madina. The findings indicate that there are gender differences in the type of networks used by migrants in migrating. For instance, some Northern women rely on kinship ties as pre-existing networks for migration, while most men hardly use this form of ties to migrate. The results indicate that irrespective of the type of network the migrants use in migration, migrants on arrival can obtain assistance by identifying the ethnic group that sped up the adaptation and integration process. Most migrants are able to engage in jobs in the informal sector. Working in groups make them able to resist some of the abuse meted to them in the market and fight as a group for their human rights when picked up by the police. As postulated by Granovetter (1983), weak and strong ties play a major role in the integration of northern migrants in Madina.

For friendship ties, participants reiterate the importance of these networks in the migration process. There are no gender differences in the use of these types of networks in the migration process. However, more women tend to use friendship ties than men who rely on ethnic groups to access the Madina market jobs. In a nutshell both men and women relied on kinship, ethnic, and friendship social networks. Regarding access to accommodation on arrival, women are able to secure accommodation on their first day compared to men. Men need to build trust 
between the new migrants and the old ethnic group members in Madina. It is also worth noting that men tend to rely more on social networks than women to get access to jobs that usually require significant capital. Male migrants have to work in groups to save enough money to acquire trucks to engage in the truck pushing business.

Gendered Ethnic spaces: Ethnicity plays a major role in the analysis because it is tied to the heterogeneous (about 31 linguistic groups) nature of the ethnic groups in the three northern regions. The ethnic groups are recreated in Madina and offer peaceful co-existence with the observation of boundaries. The findings related to gendered ethnic spaces is quite intriguing. There is an invisible demarcation of these ethnic spaces and places of accommodation as well as work sites. Two types of invisible boundaries exist, namely 1) occupational boundaries and 2) places of accommodation. These migrants' boundaries/territories are collectively observed by these migrants. This situation augured well for peaceful co-existence with fewer conflicts among migrants in Madina. In addition, there are creations of ethnic networks, associations, and ethnic communities. Through these ethnic networks, migrants feel a sense of community. Both social and emotional support is offered to migrants who are identified as ethnic group members. For instance, a head pan was used in an occupational demarcation between the Mamprusis and the Dagombas. Jobs in the market are also on ethnic lines. The sale of charcoal is for the Sissala women, while the Dagaaba and Frafras engage in local beer brewing (pito). In terms of accommodation spaces, Dagombas are located at Atima while the Sissalas are at La Nkwantanang.

As discussed, the study has shown that social networks, specifically, strong and weak ties, serve as channels for migration for Northern migrants. Some migrants appreciated the ethnic groups and associations that provided them with the necessary resources to thrive in Madina. According to Barth (2012), ethnic boundaries and spaces offer a sense of community by providing information on job opportunities, social and emotional support to members within the ethnic boundary. As ethnic spaces offer security and protection for migrants, some participants equally argue that such spaces are also avenues for breeding existing conflicts from home origins. 


\section{Conclusion and Policy Implications}

These findings demonstrate the gendered patterns of social networks used by Northern migrants. The study found that strong ties facilitated the initial migration process. However, migrants relied on weak ties (friendship and ethnic networks) to access Madina's job market and accommodation places. Creating boundaries at worksites and accommodation reinforced migrant communities serving as safe havens for most migrants in a new destination (Barth, 2012; Awumbila et al., 2017). The results indicate that migrants employ strong ties (kinship relations) in migrating. In contrast, weak ties are essential for long-term migrants' assimilation in the informal economy.

One of the limitations of this study is the generalizability — it cannot be generalized to Madina's migrant population since the focus was on individual experiences of specific northern migrants. Despite this limitation, the study is contributing to ongoing research on migration trends and the gendered social networks used in the migration and transitioning into new communities in urban centres. Concerning policy implications, North-South migration is an ongoing process, and migrants' work in the informal sector are undervalued and less paid. Northern migrants work in the informal economy contributing significantly to the economy's development by paying taxes and remittances sent to diversify incomes in poor households. There is a need for state agencies and non-governmental organizations (NGOs) to ensure that these northern migrants in Accra are not exploited and abused in the urban centres in the course of their rendering services to the public. More research needs to focus on these young migrants' intersectionality and vulnerabilities as they navigate the informal economy in these urban centres in the South.

\section{References}

Alcalá, M. J. (2006). UNFPA State of World Population: A Passage to Hope: Women and International Migration. UN.

Adepoju, A. (2002). Fostering free movement of persons in West Africa: Achievements, constraints, and prospects for intraregional migration. International migration, 40(2), 3-28. 
Afriyie, K., Abass, K., \& Boateng, M. (2015). A journey to the south: socio-economic implications for young female head porters in the central business district of Kumasi, Ghana. International Journal of Migration and Residential Mobility, 1 (2), 176-194.

Awumbila, M. (2015). Women moving within borders: Gender and internal migration dynamics in Ghana. Ghana Journal of Geography, 7(2), 132-145.

Awumbila, M., \& Ardayfio-Schandorf, E. (2008). Gendered poverty, migration and livelihood strategies of female porters in Accra, Ghana. Norsk Geografisk Tidsskrift-Norwegian Journal of Geography, 62(3), 171-179.

Awumbila, M. (2005). Gender, Rural Livelihoods and Health in Ghana: A Study of Mangrove Exploitation in the Lower Volta. Paper presented at the $48^{\text {th }}$ Annual Meeting of the African Studies Association. Washington, DC.

Awumbila, M. (2015). Women moving within borders: Gender and internal migration dynamics in Ghana. Ghana Journal of Geography, 7(2), 132-145.

Awumbila, M., Deshingkar, P., Kandilige, L., Teye, J. K., \& Setrana, M. (2019). Please, thank you and sorry-brokering migration and constructing identities for domestic work in Ghana. Journal of Ethnic and Migration Studies, 45(14), 2655-2671.

Awumbila, M., Owusu, G., \& Teye, J. K. (2014). Can rural-urban migration into slums reduce poverty? Evidence from Ghana. Migrating out of Poverty RPC Working Paper 13 (https://www.gov.uk/research-for-development-outputs/can-rural-urban-migration-intoslums-reduce-poverty-evidence-from-ghana-migrating-out-of-poverty-rpc-workingpaper-13)

Awumbila, M., Teye, J. K., \& Yaro, J. A. (2017). Social networks, migration trajectories and livelihood strategies of migrant domestic and construction workers in Accra, Ghana. Journal of Asian and African Studies, 52(7), 982-996.

Barbour, R. (2008). Doing focus groups. Sage.

Barth, F. (2012). Boundaries and connections. In signifying identities (pp. 25-44). Routledge.

Bob-Milliar, G. M. (2011). 'Te Nyəgeyeng Gbengbenoe!' ('We are holding the Umbrella very tight!'): Explaining the popularity of the NDC in the upper west region of Ghana. Africa: Journal of the International African Institute, 455-473. 
Chant, S. (1998). Households, gender and rural-urban migration: reflections on linkages and considerations for policy. Environment and urbanization, 10(1), 5-22. Creswell, J. W. (2009). Mapping the field of mixed methods research. Journal of Mixed Methods Research, 3 (2), 95-108.

De Haan, A. (1999). Livelihoods and poverty: The role of migration-a critical review of the migration literature. The Journal of Development Studies, 36(2), 1-47.

De Haas, H. (2007). Turning the tide? Why development will not stop migration. Development and change, 38(5), 819-841.

Deshingkar, P. (2012). Environmental risk, resilience and migration: implications for natural resource management and agriculture. Environmental Research Letters, 7(1), 015603

Ellis, F. (2003). A livelihoods approach to migration and poverty reduction. Norwich: Department for International Development (DFID).

Granovetter, M. (1995). Getting a job: a study of contacts and careers. Chicago, IL: University of Chicago.

Granovetter, M. (1983). The strength of weak ties: A network theory revisited. Sociological theory, 201-233.

Hagen-Zanker, J., \& Mallett, R. (2016). Journeys to Europe. The Role of Policy in Migrant Decision-Making ODI Insights.

Hashim, I., \& Thorsen, D. D. (2011). Child migration in Africa. Zed Books Ltd.

Henry, S., Schoumaker, B., \& Beauchemin, C. (2004). The impact of rainfall on the first outmigration: A multi-level event-history analysis in Burkina Faso. Population and environment, 25(5), 423-460.

Jolly, S., Reeves, H., \& Piper, N. (2005). Gender and migration: Overview report. (https://www.ssatp.org/sites/ssatp/files/publications/HTML/Gender-

RG/Source\%20\%20documents/Technical\%20Reports/Gender\%20Research/TEGEN7\%2 0BRIDGE\%20Gender\%20and\%20Migration\%200verview.pdf )

Mensah-Bonsu, A. (2003). Migration and environmental pressure in northern Ghana. PhD Thesis, Vrije Universiteit Amsterdam, Amsterdam.

Mitchell, J. C. (Ed.). (1969). Social networks in urban situations: analyses of personal relationships in Central African towns. Manchester University Press.

Moustakas, C. (1994). Phenomenological research methods. Sage publications. 
Nikoi, E. G. A., Arthur, I. K., \& Nambe, M. Y. (2019). Examining the Role of Networks in Conflict-Induced Migration in Bawku. Ghana Journal of Geography, 11(1), 72-86.

Rademacher-Schulz, C., Schraven, B., \& Mahama, E. S. (2014). Time matters: shifting seasonal migration in Northern Ghana in response to rainfall variability and food insecurity. Climate and Development, 6(1), 46-52.

Roulston, K. (2010). Reflective interviewing: A guide to theory and practice. Sage.

Songsore, J. (2009). The urban transition in Ghana: Urbanization, national development and poverty reduction. University of Ghana, Legon-Accra. Study Prepared for the IIED as part of its Eight country Case studies on Urbanisation. (https://pubs.iied.org/pdfs/G02540.pdf )

Teye, J. K. (2018). Environmental change and migration in Africa. In Migration in a Globalizing World: Perspectives from Ghana (pp. 97-115). Sub-Saharan Publishers.

Van der Geest, K. (2011). North-South migration in Ghana: what role for the environment? International Migration, 49, e69-e94.

Vertovec, S. (2009). Transnationalism. Routledge.

Wrigley-Asante, C. (2008). Men are poor but women are poorer: Gendered poverty and survival strategies in the Dangme West District of Ghana. Norsk Geografisk TidsskriftNorwegian Journal of Geography, 62(3), 161-170.

Yaro, J. A., Teye, J., \& Bawakyillenuo, S. (2015). Local institutions and adaptive capacity to climate change/variability in the northern savannah of Ghana. Climate and Development, 7(3), 235-245.

Yaro, J. A. (2013). The perception of and adaptation to climate variability/change in Ghana by small-scale and commercial farmers. Regional Environmental Change, 13(6), 1259-1272.

Yaro, J. A. (2006). Is deagrarianisation real? A study of livelihood activities in rural northern Ghana. Journal of Modern African Studies, 125-156.

Yeboah, T. (2020). Future aspirations of rural-urban young migrants in Accra, Ghana. Children's Geographies, 1-14.

Yeboah, T. (2017). Navigating precarious employment: Social networks among migrant youth in Ghana. IDS Bulletin Transforming Development Knowledge, 48 (3). (https://bulletin.ids.ac.uk/index.php/idsbo/article/view/2871/ONLINE\%20ARTICLE ) 